BANGLADESH J CHILD HEALTH 2009; VOL 33 (3): 100-103

\title{
RDWI is Better Discriminant than RDW in Differentiation of Iron Deficiency Anaemia and Beta Thalassaemia Trait
}

\author{
AYATUN NESA ${ }^{1}$, MD. ABU TAYAB ${ }^{2}$, TUHIN SULTANA ${ }^{3}$, LUBNA KHONDKER ${ }^{4}$, \\ MD. QUDDUSUR RAHMAN ${ }^{5}$, MD. ANWARUL KARIM ${ }^{6}$, A N NASHIMUDDIN AHMED $^{7}$
}

\begin{abstract}
Iron deûciency anemia (IDA) and beta-thalassemia trait (BTT) are the common causes of microcytic hypochromic anaemia. Several discrimination indices have been introduced to discriminate quickly these similar entities via parameters obtained from automated cell counter. The purpose of the study was to compare the value of two discrimination indices, red cell distribution width index (RDWI) and red cell distribution width (RDW) in differentiation of BTT and IDA. This study consists of 57 cases of $B T T$ and 72 cases of IDA. Severe anaemia ( $<7.0 \mathrm{gm} / \mathrm{dl}$ ) had been excluded because these cases are not confused with BTT cases in practice. Sensitivity, specificity, positive and negative predictive values and Youden's index of both indices in differentiation of BTT and IDA had been calculated. RDWI appears to be reliable and useful index for differentiation of iron deficiency anaemia and beta thalassaemia trait. Again RDWI is better than RDW in differentiating BTT from IDA.
\end{abstract}

Key words: Microcytic hypochromic anemia, discrimination indices.

\section{Introduction}

Microcytic hypochromic anaemia is a very common haematological abnormality in clinical practice ${ }^{1}$. Two most common causes of microcytic hypochromic anaemia are iron deficiency anaemia (IDA) and beta thalassaemia trait (BTT), which are sometimes difficult to differentiate clinically and by routine laboratory examination ${ }^{2,3}$. The differentiation between BTT and IDA relies on the measurement of serum ferritin, serum iron and $\mathrm{HbA}_{2}$ levels. But these methods are expensive and time consuming ${ }^{4}$. Again morphological appearance of red cells in blood film in IDA and BTT mimics so closely that it becomes sometimes very difficult in differentiating these two conditions ${ }^{5}$. New automated blood cell counter provide an index of red cell volume distribution width (RDW), an important parameter in differentiation of IDA and $\mathrm{BTT}^{6}$. The RDW

1. Assistant Professor, Department of Pathology, Ibrahim Medical College, Dhaka

2. Junior Consultant, Department of Paediatrics Medicine, Dhaka Shishu Hospital, Dhaka

3. Assistant Professor, Department of Clinical Pathology, BSMMU, Dhaka

4. Assistant Professor, Department of Medical Statistics, BSMMU, Dhaka

5. Associate Professor, Department of Clinical Pathology, BSMMU, Dhaka

6. Associate Professor, Department of Paediatric Haematooncology, BSMMU, Dhaka

7. Professor and Chairman, Department of Clinical Pathology, BSMMU, Dhaka

Correspondence: Dr. Ayatun Nesa quantitatively measures red blood cell size variation, computed directly from the RBC histogram and is calculated as a standard statistical value, the coefficient of variation of the volume distribution ${ }^{7}$. McClure et al showed that RDW is the first index of the routine blood cell count to become abnormal during the development of iron deficiency ${ }^{8}$. Another red cell discriminant function, red cell distribution width index (RDWI) had been described by Jayabose et al ${ }^{9}$ would be reliable discrimination index in differentiation of BTT and IDA ${ }^{10-11}$. RDWI is a cell counter based formula, calculated as (MCV $\times$ RDW /RBC) ${ }^{9}$. The purpose of the study was to compare diagnostic value RDWI and RDW in differentiation of IDA and BTT.

\section{Materials and Methods}

This present cross-sectional study was carried out in the Department of Clinical Pathology, BSMMU, Dhaka in collaboration with Department of Haematooncology and Haematology, BSMMU, Dhaka. The newly clinically diagnosed cases of BTT and IDA were selected for this study. Cases were selected as beta thalassaemia trait and iron deficiency anaemia on the basis of two standard tests, $\mathrm{Hb}$ electrophoresis and serum ferritin estimation. Patients with $\mathrm{HbA}_{2}$ more than $3.5 \%$ were identified as BTT cases and 
patients with serum ferritin less than $12 \mathrm{ng} / \mathrm{ml}$ were identified as IDA cases. After taking informed written consent, a total 129 patients of 1 to 60 years of age were selected in this study. Among them 57 cases were BTT and 72 cases were IDA. Complete blood counts including red cell indices were obtained by automated analyzer in all the patients. Differentiation between IDA and BTT were done by using red cell distribution width (RDW) and red blood cell distribution width index (RDWI), these were calculated from parameters provided by automated analyzer. The differential value of RDW and RDWI were given in Table-I.

Table-I

Value of discrimination indices used in evaluation

\begin{tabular}{lcc}
\hline Indices & $\begin{array}{c}\text { In favour } \\
\text { of IDA }\end{array}$ & $\begin{array}{c}\text { In favour } \\
\text { of BTT }\end{array}$ \\
\hline RDWI (MCV X RDW / RBC) & $>220$ & $<220$ \\
RDW (\%) & $>14$ & $<14$ \\
\hline
\end{tabular}

Then all the data were analyzed by standard statistical methods using SPSS 16 software. Validity of both discrimination indices in differentiation of BTT and IDA were evaluated by calculating their sensitivity, specificity, positive predictive value (PPV), negative predictive value (NPV) and Youden's index (YI).

\section{Results}

Fifty seven cases were identified as BTT in which mean $\mathrm{Hb} \mathrm{A}$ level was found $4.5 \%$ and 72 cases were identified as IDA whose mean serum ferritin was 9.3 $\mathrm{ng} / \mathrm{ml}$. On the other hand mean serum ferritin level in BTT was found $76.1 \%$. The mean haemoglobin level was found $9.8 \mathrm{gm} / \mathrm{dl}$ in case of IDA and $10.2 \mathrm{gm} / \mathrm{dl}$ in cases of BTT. Mean MCV was found $71.8 \mathrm{fl}$ in IDA cases and $63.9 \mathrm{fl}$ in BTT cases (Table-II). There were significant differences of $\mathrm{Hb}$ level and $\mathrm{MCV}$, found in between BTT and IDA. Another important red blood cell parameter for detection of IDA and BTT is RDW. In the present study the mean RDW was found $16.4 \%$ in case of BTT and $16.9 \%$ in case of IDA. The results were not statistically significant $(p=0.269)$.

Table-II

Statistics of different values of red blood cell parameters in BTT and IDA cases

\begin{tabular}{lccc}
\hline Test & Case & Mean & Std Deviation \\
\hline $\mathrm{Hb}(\mathrm{gm} / \mathrm{dl})$ & BTT & 10.2 & \pm 0.8 \\
& IDA & 9.8 & \pm 0.9 \\
$\mathrm{MCV}(\mathrm{fl})$ & BTT & 63.9 & \pm 7.5 \\
& IDA & 71.8 & \pm 6.4 \\
$\mathrm{MCH}(\mathrm{pg})$ & BTT & 19.9 & \pm 2.9 \\
& IDA & 22.8 & \pm 2.8 \\
$\mathrm{MCHC}(\mathrm{gm} / \mathrm{dl})$ & BTT & 31.1 & \pm 1.6 \\
& IDA & 31.6 & \pm 1.8 \\
$\mathrm{RDW}(\%)$ & BTT & 16.4 & \pm 2.5 \\
& IDA & 16.9 & \pm 2.9 \\
\hline
\end{tabular}

In the present study, RDWI came out as good discriminators between BTT and IDA, as this index had both sensitivity and specificity more than $80 \%$ in detection of BTT and IDA. Sensitivity, specificity of RDWI index for detection of BTT was found $80.7 \%$, $84.7 \%$. Again for IDA, sensitivity and specificity was found $84.7 \%$ and $80.7 \%$ respectively. Youden's index (YI) takes into account both sensitivity and specificity and gives an appropriate measures of validity of a particular technique. YI of RDWI was found 65.4 , which could be reliable discriminator between $\beta$ thalassaemia trait and iron deficiency anaemia. On the other hand the sensitivity, specificity of RDW for BTT cases were found, $17.5 \%$, and $84.7 \%$ respectively and for IDA sensitivity was $84.7 \%$ and specificity was $17.5 \%$. Ultimate Youden's index was found 2.3, which would not be a good discriminator of BTT and IDA (Table-III).

Table-III

Sensitivity, specificity, PPV, NPV and YI of two discrimination indices in diagnosis of BTT and IDA

\begin{tabular}{lccccccc}
\hline Indices & $\begin{array}{c}\text { Differential } \\
\text { value }\end{array}$ & $\begin{array}{c}\text { Cases } \\
(\%)\end{array}$ & $\begin{array}{c}\text { Sensitivity } \\
(\%)\end{array}$ & $\begin{array}{c}\text { Specificity } \\
(\%)\end{array}$ & $\begin{array}{c}\text { PPV } \\
(\%)\end{array}$ & $\begin{array}{c}\text { NPV } \\
(\%)\end{array}$ & $\begin{array}{c}\text { Youden's } \\
\text { index }\end{array}$ \\
\hline RDWI (MCV $x$ & $<220$ & BTT & 80.7 & 84.7 & 80.7 & 81.3 & \\
RDW/ RBC) & $>220$ & IDA & 84.7 & 80.7 & 81.3 & 80.7 & 65.4 \\
RDW (\%) & $<14$ & BTT & 17.5 & 84.7 & 47.6 & 43.5 & \multirow{2}{*}{ (2).3 } \\
& $>14$ & IDA & 84.7 & 17.5 & 43.5 & 47.6 & \\
\hline
\end{tabular}




\section{Discussion}

The most frequently encountered diseases with mild microcytic hypochromic anaemia are BTT and IDA $^{2-3}$. The discrimination between IDA and BTT is important because MCV will not normalize in BTT if misdiagnosed as IDA and treated with iron ${ }^{4}$.

To differentiate between beta thalassaemia trait (BTT) and iron deficiency anaemia (IDA), physician needs a battery of examination including estimation of $\mathrm{HbA}_{2}$, peripheral blood film, serum ferritin, iron, TIBC (total iron binding capacity) levels and transferrin saturation $^{12}$. But these are relatively expensive, time consuming and sophisticated techniques. Red blood cell volume distribution (RDW) curves generated easily by electronic cell counters and can reliably distinguish microcytosis caused by IDA and $\mathrm{BTT}^{13}$.

RDW is a measure of anisocytosis, increases in IDA and it is normal or mild increase in BTT. Though RDW has been reported to be a good discrimination index to differentiate BTT and IDA ${ }^{7}$. Our results found that RDW more or less equally elevated in BTT and IDA. The mean value of RDW, found in IDA and BTT were $16.9 \pm 2.9 \mathrm{SD}$ and $16.4 \pm 2.5 \mathrm{SD}$ respectively. The sensitivity, specificity of RDW in detection of BTT were found, $17.5 \%$ and $84.7 \%$ and for IDA sensitivity was $84.7 \%$ and specificity was $17.5 \%$. Ultimate Youden's index was found 2.3, which would not be a good discriminator of BTT and IDA. Similar findings also reported by Ntaios et $\mathrm{al}^{4}$ and AlFadhli et $\mathrm{al}^{14}$.

In this study, RDWI came out as good discriminators between BTT and IDA, had both sensitivity and specificity more than $80 \%$ in detection of BTT and IDA. Sensitivity and specificity of RDWI in detection of BTT were found $80.7 \%$ and $84.7 \%$ respectively and for detection of IDA were found $84.7 \%$ sensitivity and $80.7 \%$ specificity. These results are consistent with the findings of Demir et $\mathrm{al}^{10}$ and Sirdah et $\mathrm{al}^{11}$. $\mathrm{YI}$ of RDWI was found 65.4, which could be reliable discriminator between BTT and IDA. There were few limitation of these study like, Haemoglobin $\mathrm{E}$ disease and traits were not included in this study.

\section{Conclusion}

From this study it can be concluded that, RDWI appears to be reliable and useful index for initial screening of microcytic hypochromic anaemia and is better than RDW in differentiating IDA from BTT.

\section{Acknowledgement}

I would like to thank all the consultants, junior doctors and staff of the Department of Clinical Pathology,
BSMMU, Dhaka for their consistent support in conducting this study.

\section{References}

1. Sankar VH, Arya V, Tewari D, Gupta UR, Pradhan M, Agarwal S. Genotyping of alpha thalassaemia in microcytic hypochromic anemia patients from North India. J Appl Genet 2006; 47: 391-95.

2. Wharton BA. Iron deficiency in children: detection and prevention. Br J Haematol 1999; 106: 270-80.

3. Olivieri NF. The beta-thalassemias. N Engl J Med 1999; 341: 99-109.

4. Ntaios G, Chatzinikolaou A, Saouli Z, Girtovitis F, Tsapanidou M, Kaiafa G, et al. Discrimination indices as screening tests for â-thalassemia trait. Ann Hematol 2007; 86: 487-91.

5. Uddin MM, Uddin MJ, Mahmud Z, Hassan SMM, Abedin AKMM, Rahman MM, et al. Value of Red Cell Distribution Width Index As A Diagnostic Tool In Iron Deficiency Anaemia And Various Congenital Haemoglobin Disorders. Bangladesh J Pathol 2006; 21: 14-18.

6. Aslan D, Gumruk F, Gurgey A, Altay C. Importance of RDW Value in Differential Diagnosis of Hypochrome Anaemias. American Journal of Hematology 2002; 69: 31-33.

7. Novak RW. Red Blood Cell Distribution Width in Pediatric Microcytic Anaemias. Pediatrics 1987; 80: 251-54.

8. McCulure S, Custer E, Bessmann JD. Improved detection of early iron deficiency in nonanaemic subject. JAMA 1985; 253: 1021-23.

9. Jayabose S, Giavanelli J, Levendoglu-Tugal O, Sandoval C, Özkaynak F, Visintainer P. Differentiating iron deficiency index. J Pediatr Hematol 1999; 21: 314.

10. Demir A, Yarali N, Fisgin T, Duru F, Kara A. Most reliable indices in differentiation between thalassemia trait and iron deûciency anemia. Pediatr Int 2002; 44: 612-16.

11. Sirdah M, Tarazi I, Najjar EA, Haddad RA. Evaluation of the diagnostic reliability of different 
indices and formulas in the differentiation of the $b$ thalassaemia minor from iron deficiency in Palestinian population. Int J Lab Hem 2008; 30 : 324-30.

12. Lima CSP, Reis ARC, Gotto HZW, Saad STO, Costa FF. Comparison of red cell distribution width and a red cell discriminant function incorporating volume dispersion for distinguishing iron deficiency from beta thalassemia trait in patients with microcytosis. Sao Paulo Medical Journal 1996; 114: 1265-65.
13. Johnson CS, Tegos C, Beutler E. Thalassaemia Minor: Routine Erythrocyte Measurements and Differentiation from Iron Deficiency. Am J Clin Pathol 1983; 80: 31-36.

14. AlFadhli SM, Al-Awadhi AM, AlKhaldi D. Validity Assessment of Nine Discriminant Functions Used for the Differentiation between Iron Deficiency Anemia and Thalassemia Minor. J Trop Pediatr 2006; 53: 93-97. 